\title{
HER2-targeted therapy influences CTC status in metastatic breast cancer
}

\author{
Thomas M. Deutsch ${ }^{1}$. Sabine Riethdorf ${ }^{2} \cdot$ Carlo Fremd $^{3} \cdot$ Manuel Feisst $^{4} \cdot$ Juliane Nees $^{1} \cdot$ Chiara Fischer $^{1}$. \\ Andreas D. Hartkopf ${ }^{5} \cdot$ Klaus Pantel $^{2} \cdot$ Andreas Trumpp $^{6,7} \cdot$ Florian Schütz $^{1} \cdot$ Andreas Schneeweiss $^{3,8}$. \\ Markus Wallwiener ${ }^{1}$ (D)
}

Received: 12 March 2020 / Accepted: 11 May 2020 / Published online: 20 May 2020

(c) The Author(s) 2020

\begin{abstract}
Purpose As an independent, negative-prognostic biomarker for progression-free survival (PFS) and overall survival (OS), circulating tumor cells (CTCs) constitute a promising component for developing a liquid biopsy for patients with metastatic breast cancer (MBC). The effects of HER2-targeted therapy such as trastuzumab, pertuzumab, T-DM1, and lapatinib on CTC status and longitudinal enumeration were assessed in this trial.

Methods CTC status of 264 patients with MBC was analyzed prior to and after 4 weeks of a new line of palliative systemic therapy. CTCs were assessed using CellSearch ${ }^{\circledR}$. Three groups were compared: patients with HER2-positive MBC receiving ongoing HER2-targeted therapy $(n=28)$, patients with de novo HER2-positive MBC and no HER2-targeted therapy in the last 12 months prior to enrollment and start of HER2-targeted therapy $(n=15)$, and patients with HER2-nonamplified disease and no HER2-targeted therapy $(n=212)$.

Results Positive CTC status ( $\geq 5$ CTC/7.5 ml blood) at enrollment was observed in the 3 groups for 17.9, 46.7, and 46.2\% $(p=0.02)$ of patients, respectively. At least one CTC/7.5 ml was seen in 28.6, 53.3, and 67.0\% $(p<0.001)$ of these patients. Furthermore, 3.6, 40.0, and 3.3\% ( $p<0.001)$ of the patients had at least one HER2-positive CTC. After 4 weeks of therapy $7.1,0.0$, and $31.1 \%(p=0.001)$ of patients had still a positive CTC status $(\geq 5 \mathrm{CTC} / 7.5 \mathrm{ml}$ blood). At least one CTC/7.5 ml was still observed in 25.0, 20.0, and 50.5\% ( $p=0.004)$ of the patients. Furthermore, 7.1, 0.0, and 1.9\% $(p=0.187)$ had at least one HER2-positive CTC. After 3 months of therapy, 35.7, 20.0, and 28.3\% ( $p=0.536$ ) showed disease progression.

Conclusions HER2-targeted therapy seems to reduce the overall CTC count in patients with MBC. This should be taken into account when CTC status is used as an indicator for aggressive or indolent metastatic tumor disease.
\end{abstract}

Keywords Metastatic breast cancer (MBC) - Human epidermal growth factor receptor 2 (HER2) - Circulating tumor cells (CTC) · HER2-targeted therapy

Markus Wallwiener

markus.wallwiener@med.uni-heidelberg.de

1 Department of Gynecology and Obstetrics, University Hospital Heidelberg, Im Neuenheimer Feld 440, 69120 Heidelberg, Germany

2 Institute of Tumor Biology, University Hospital Hamburg-Eppendorf, Martinistraße 52, 20246 Hamburg, Germany

3 Department of Medical Oncology, National Center for Tumor Diseases, Im Neuenheimer Feld 460, 69120 Heidelberg, Germany

4 Institute of Medical Biometry and Informatics, University of Heidelberg, Im Neuenheimer Feld 130.3, 69120 Heidelberg, Germany
5 Department of Gynecology and Obstetrics, University Hospital Tübingen, Calwerstraße 7, 72076 Tübingen, Germany

6 Division of Stem Cells and Cancer, German Cancer Research Center (DKFZ), Im Neuenheimer Feld 280, 69120 Heidelberg, Germany

7 Heidelberg Institute for Stem Cell Technology and Experimental Medicine (HI-STEM gGMBH), Im Neuenheimer Feld 280, 69120 Heidelberg, Germany

8 German Cancer Research Center (DKFZ), Im Neuenheimer Feld 280, 69120 Heidelberg, Germany 


\section{Background}

Worldwide, metastatic breast cancer (MBC) is a major cause of cancer-related death in women [1-3]. MBC, also called stage IV breast cancer, is considered to be not curable [4]. The intent of therapies is therefore palliative and meant to stabilize the disease with tolerable side effects for the patients. The human epidermal growth factor receptor 2 (HER2) gene is overexpressed in about $10-30 \%$ of patients with invasive breast cancer [5-7]. In the past, HER2 gene expression was correlated with poor clinical outcome in early breast cancer and metastatic disease alike [8-10]. Since the development of HER2-targeted therapies such as trastuzumab, pertuzumab, T-DM1, and lapatinib, prognosis has changed dramatically. In hormone-receptor positive primary breast cancer, HER 2 positivity now even represents a favorable predictor for overall survival (OS) [5]. Newfound HER 2 overexpression in biopsies of metastases allow additional, well-tolerated therapy options in the metastasized situation.

Apart from solid metastases, a liquid biopsy as detector and surrogate of the systemic tumor burden is needed to take into account the heterogeneity of the disease [11]. As an independent, negative-prognostic biomarker for progression-free survival (PFS) and OS, circulating tumor cells (CTCs) constitute a promising component for developing a liquid biopsy for patients with MBC [12-14]. Indeed, CTCs are a versatile tool in clinical therapy management and can distinguish between aggressive and indolent metastatic tumor disease [15-17]. CTC monitoring as a prognostic tool in $\mathrm{MBC}$ has therefore been introduced in several guidelines such as ASCO and AGO [18, 19]. However, CTCs could not yet show in clinical trials to be predictive for clinical benefit when used to guide decisions on systemic therapy [18]. Independent of clinical and molecular variables, $\geq 5$ CTCs per $7.5 \mathrm{ml}$ blood are regarded as the threshold for stratification [20].

As CTCs reflect a subpopulation of the total tumor cell population, characterization and treatment of CTC might be a promising tool for optimizing therapy [21]. Meng et al. demonstrated the presence of HER2-positive CTCs in patients with HER2-negative primary tumors [22]. HER2-positive CTC even proved to be a relevant prognostic factor, independent of primary tumor and metastatic phenotype [23]. However, the therapeutic and predictive relevance of HER2-positive CTC phenotypes is still the subject of controversial discussion [24], and more clinical trials are needed to evaluate their clinical significance.

Retrospective studies and xenograft models suggest that HER2-targeted monoclonal antibody therapies might even be able to target both HER2-nonamplified cancer cells and cancer stem cell populations via antibody-dependent, cell-mediated cytotoxicity (ADCC) [25]. In a phase-II trial, trastuzumab was able to eliminate CTCs independent of HER2 status and decreased the incidence of clinical relapses [26]. On the other hand, another phase-II trial with the intention to treat CTCs in HER2-nonamplified, nonmetastatic breast cancer had to be stopped and showed that trastuzumab does not decrease the detection rate of CTCs [27].

To further investigate these controversial findings, this retrospective study was conducted to demonstrate the immediate effect of HER2-targeted therapies on CTCs in the metastatic setting.

\section{Patients and methods}

The CTC study of the National Center for Tumor Diseases (NCT) enrolls patients before administering a new line of systemic therapy when MBC or progressive disease (PD) of $\mathrm{MBC}$ is diagnosed. Blood draws are performed at enrollment and 4 weeks after starting a new line of systemic therapy. Since March 2010, 505 patients were enrolled (Fig. 1). In this retrospective trial, all patients for whom CTC data were recorded at baseline and after 4 weeks of therapy were included $(n=264)$. Exclusion criteria were: no blood draw after 4 weeks of therapy $(n=207)$, no blood draw at enrollment $(n=16)$, patients who were already included in the trial $(n=13)$, no follow-up information $(n=9)$, no metastatic disease $(n=3)$, or withdrawal of patient's consent to participate in the study $(n=2)$. Furthermore, $\geq 5$ CTCs per $7.5 \mathrm{ml}$ peripheral blood was defined as CTC-positive [20]. Criteria for inclusion were measurable progressive metastatic disease according to the Response Evaluation Criteria in Solid Tumors (RECIST) criteria [28], age $>18$ years, and written informed consent to participate in the study. Ethical approval was obtained from the Ethics Committee of the Medical Faculty of the University of Heidelberg, approval no. S-295/2009.

The study population was divided into 3 groups: patients with HER2-positive MBC with HER2-targeted therapy in the new and previous therapy line ("HER2 therapy", $n=28$ ); patients with HER2-positive MBC and no HER2-targeted therapy in the last 12 months prior to enrollment and start of HER2-targeted therapy ("New HER2 therapy", $n=15$ ); and patients with HER2-nonamplified disease and no HER2targeted therapy ("No HER2 therapy", $n=212$ ). The "New HER2 therapy" group included patients that were pretreated with chemotherapy and/or endocrine therapy for MBC, since 5-20\% of patients show newfound HER2 overexpression in biopsies of metastases [29-31].

Therapy response was evaluated every 3 months via CT and/or MRI scan and categorized according to the Response Evaluation Criteria in Solid Tumors (RECIST) 
Fig. 1 Flow of patients

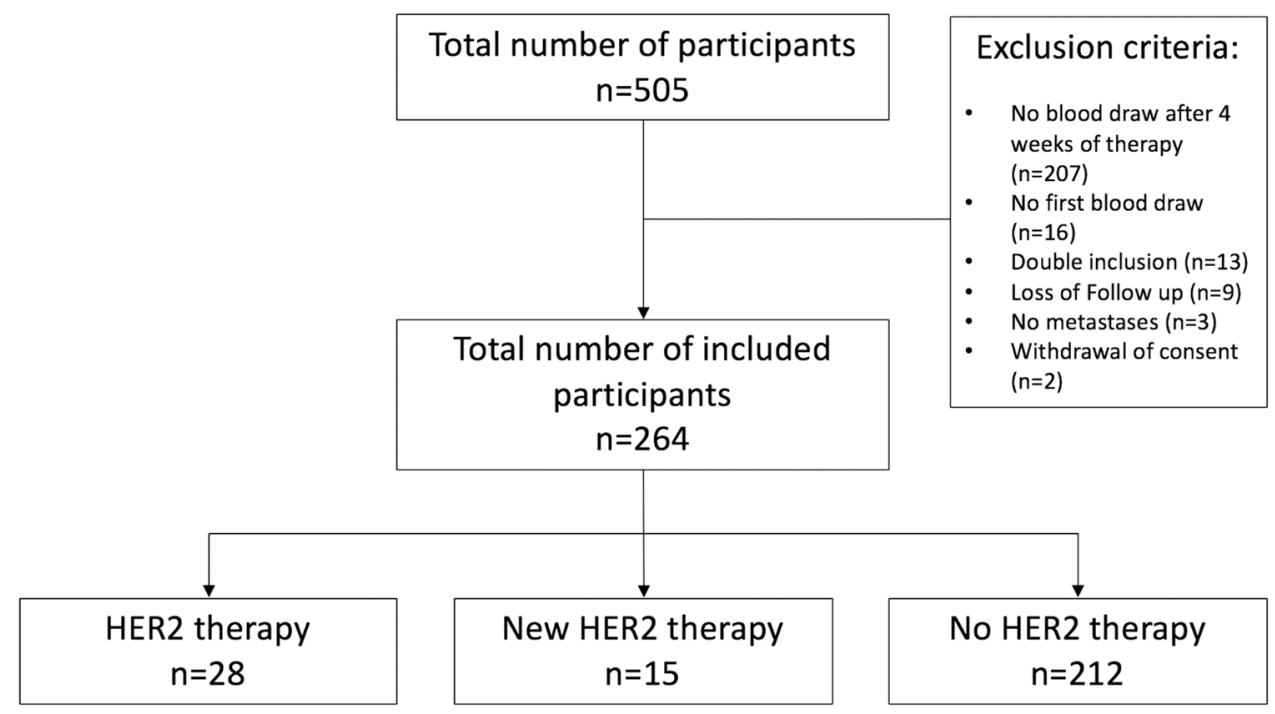

as progressive disease (PD), stable disease (SD), complete remission (CR), or partial response (PR) [28].

Peripheral blood for enumerating CTCs was collected in $7.5 \mathrm{ml}$ CellSave tubes (J Janssen Diagnostics, LLC, Raritan, NJ, USA). The blood samples were processed and analyzed within 96 h, using the CellSearch ${ }^{\mathrm{TM}}$ assay (CellSearch ${ }^{\mathrm{TM}}$ Epithelial Cell Kit/CellSpotter ${ }^{\mathrm{TM}}$ Analyzer, Janssen Diagnostics, LLC, Raritan, NJ, USA), strictly following the manufacturer's instructions. The CellSearch ${ }^{\mathrm{TM}}$ assay uses epithelial cell adhesion molecule (EpCAM)-based immunomagnetic enrichment and immunofluorescence with antibodies against keratins and CD45, differentiating between debris, hematopoietic cells, and epithelial cells [32], and provides high intra-observer, interobserver, and interinstrument agreement that led to FDA approval [33-36]. EpCAM-positive cells were labeled with the nuclear dye 4',6-diamidino-2-phenylindole (DAPI) and immunostained with monoclonal keratin and CD45-specific antibodies. The CellSpotter ${ }^{\mathrm{TM}}$ Analyzer was used by trained staff to detect CTCs as previously described [37-40]. Here, $\geq 5$ CTCs per $7.5 \mathrm{ml}$ blood was considered as CTC-positive [20]. The anti-HER2 antibody fluorescein isothiocyanate (FITC, CellSearch tumor-phenotyping reagent HER2, Janssen Diagnostics LLC, Raritan, NJ, USA) was used to characterize HER2 expression in CTCs by applying the CellSearch technology, as described previously [19, 26, 27]. HER2 score was determined according to the intensity of HER2-specific immunofluorescence and characterized as negative (0), weak $(1+)$, moderate $(2+)$, or strong $(3+)$. CTC status was considered HER2-positive if at least one CTC exhibited strong (3+) or moderate (2+) HER2 staining [8].

Clinical characteristics of the cohort were described as absolute and relative frequencies for binary and ordinal variables, as well as mean and $95 \%$ confidence intervals for continuous variables. Mean PFS and OS times were estimated counting from the timepoint of study enrollment. Differences between groups were analyzed by Chi-squared tests (categorical data) and $t$ tests (continuous variables). Statistical analyses were performed using R (version 3.6.0) [41]. Figures were generated using Microsoft Office Version 16.30. Since this is an exploratory study, $p$ values should be interpreted in a descriptive sense. $p$ values smaller than 0.05 were defined as significant.

\section{Results}

Initially, CTC-positive ( $\geq 5$ CTC/7.5 ml blood) were 17.9, 46.7 , and $46.2 \%(p=0.02)$ of patients in the three groups "HER2 therapy", "New HER2 therapy", and "No HER2 therapy" as shown in Table 1. At least one CTC/7.5 ml was detected in 28.6, 53.3, and $67.0 \%(p<0.001)$ of these patients. In total 3.6, 40.0, and 3.3\% $(p<0.001)$ of the study population had at least one CTC with HER2 positivity. After 4 weeks of therapy, 7.1, 0.0, and 31.6\% $(p=0.001)$ of patients were still CTC-positive. The black bars in Fig. 2 demonstrate the trend of CTC positivity under therapy. At least one CTC/7.5 ml was detected in 25.0,20.0, and 50.5\% $(p=0.004)$ of the patients in the three groups after 4 weeks of therapy. This trend is visualized in Fig. 3. At this timepoint $7.1,0.0$, and $1.9 \%(p=0.187)$ of the patients had at least one CTC showing HER2 expression.

Progression of disease (PD) after 3 months of therapy in the study was observed for $10(35.7 \%), 3(20.0 \%)$, and 60 (28.3\%) patients, respectively, in the three treatment groups $(p=0.536)$. These patients showed higher rates of CTCs after 4 weeks of therapy than patients with at least stable disease. In all, 10.0, 0.0, and 50.0\% ( $p=0.019)$ of these patients were CTC-positive after 4 weeks of therapy if disease had progressed. At least one CTC/7.5 ml was detected in 30.0, 
Table 1 Patient characteristics and rate of CTC status divided by therapy groups after enrollment

\begin{tabular}{|c|c|c|c|c|c|}
\hline & & HER2 therapy & New HER2 therapy & No HER2 therapy & $p$ \\
\hline Total & $n$ & 28 & 15 & 212 & \\
\hline$\geq 1 \mathrm{CTC}$ at enrollment & Rate & $28.6 \%$ & $53.3 \%$ & $67.0 \%$ & $<0.001$ \\
\hline$\geq 5 \mathrm{CTC}$ at enrollment & Rate & $17.9 \%$ & $46.7 \%$ & $46.2 \%$ & 0.02 \\
\hline$\geq 1$ HER2-positive CTC at enrollment & Rate & $3.6 \%$ & $40.0 \%$ & $3.3 \%$ & $<0.001$ \\
\hline$\geq 1 \mathrm{CTC}$ after 4 weeks & Rate & $25.0 \%$ & $20.0 \%$ & $50.5 \%$ & 0.004 \\
\hline$\geq 5$ CTC after 4 weeks & Rate & $7.1 \%$ & $0.0 \%$ & $31.6 \%$ & 0.001 \\
\hline$\geq 1$ HER2-positive CTC after 4 weeks & Rate & $7.1 \%$ & $0.0 \%$ & $1.9 \%$ & 0.187 \\
\hline \multirow[t]{2}{*}{ PD after 3 months } & $n$ & 10 & 3 & 60 & \\
\hline & Rate & $35.7 \%$ & $20.0 \%$ & $28.3 \%$ & 0.536 \\
\hline $\mathrm{PD}+\geq 1 \mathrm{CTC}$ at enrollment & Rate & $40.0 \%$ & $33.3 \%$ & $75.0 \%$ & 0.036 \\
\hline $\mathrm{PD}+\geq 5 \mathrm{CTC}$ at enrollment & Rate & $30.0 \%$ & $33.3 \%$ & $55.0 \%$ & 0.284 \\
\hline $\mathrm{PD}+\geq 1$ HER 2 positive $\mathrm{CTC}$ at enrollment & Rate & $10.0 \%$ & $33.3 \%$ & $5.0 \%$ & 0.151 \\
\hline $\mathrm{PD}+\geq 1 \mathrm{CTC}$ after 4 weeks & Rate & $30.0 \%$ & $33.3 \%$ & $66.7 \%$ & 0.056 \\
\hline $\mathrm{PD}+\geq 5 \mathrm{CTC}$ after 4 weeks & Rate & $10.0 \%$ & $0.0 \%$ & $50.0 \%$ & 0.019 \\
\hline $\mathrm{PD}+\geq 1$ HER2-positive CTC after 4 weeks & Rate & $0.0 \%$ & $0.0 \%$ & $5.0 \%$ & 0.713 \\
\hline Age at diagnosis $\mathrm{BC}$ & $\begin{array}{l}\text { Mean } \\
(95 \% \mathrm{CI})\end{array}$ & $\begin{array}{l}46.6 \text { years } \\
(42.2-51.0)\end{array}$ & $\begin{array}{l}54.9 \text { years } \\
(50.6-59.2)\end{array}$ & $\begin{array}{l}52.2 \text { years } \\
(50.7-53.8)\end{array}$ & 0.032 \\
\hline Age at enrollment & $\begin{array}{l}\text { Mean } \\
(95 \% \mathrm{CI})\end{array}$ & $\begin{array}{l}54.7 \text { years } \\
(50.2-59.1)\end{array}$ & $\begin{array}{l}59.1 \text { years } \\
(54.5-63.7)\end{array}$ & $\begin{array}{l}59.3 \text { years } \\
(59.1-59.5)\end{array}$ & 0.059 \\
\hline Number of previous lines of $\mathrm{CHT}$ for $\mathrm{MBC}$ & $\begin{array}{l}\text { Mean } \\
(95 \% \mathrm{CI})\end{array}$ & $\begin{array}{l}1.9 \\
(1.3-2.5)\end{array}$ & $\begin{array}{l}0.4 \\
(0.2-0.7)\end{array}$ & $\begin{array}{l}1.5 \\
(1.3-1.7)\end{array}$ & 0.570 \\
\hline Previous endocrine therapy for $\mathrm{MBC}$ & Rate & $39.3 \%$ & $20.0 \%$ & $52.4 \%$ & 0.033 \\
\hline PFS & $\begin{array}{l}\text { Mean } \\
(95 \% \mathrm{CI})\end{array}$ & $\begin{array}{l}8.8 \text { months } \\
(5.7-11.8)\end{array}$ & $\begin{array}{l}14.5 \text { months } \\
(5.4-23.7)\end{array}$ & $\begin{array}{l}10.6 \text { months } \\
(8.7-12.4)\end{array}$ & 0.755 \\
\hline OS & $\begin{array}{l}\text { Mean } \\
(95 \% \mathrm{CI})\end{array}$ & $\begin{array}{l}26.1 \text { months } \\
(19.8-32.3)\end{array}$ & $\begin{array}{l}42.7 \text { months } \\
(33.0-52.5)\end{array}$ & $\begin{array}{l}26.8 \text { months } \\
(23.9-29.6)\end{array}$ & 0.526 \\
\hline
\end{tabular}

Fig. 2 Rate of patients with $\geq 5$ CTCs at enrollment and after 4 weeks of therapy and patients with progression of disease (PD) after 3 months

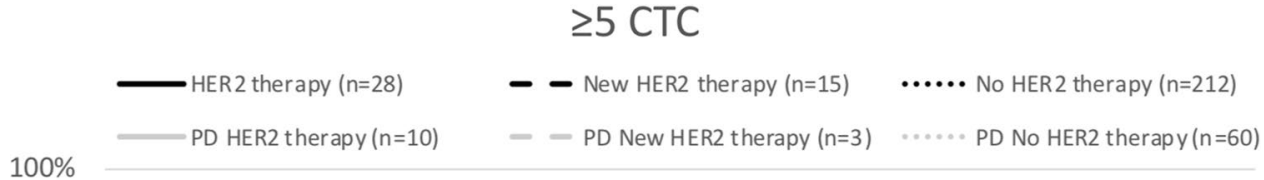

$100 \%$

$80 \%$

$60 \%$

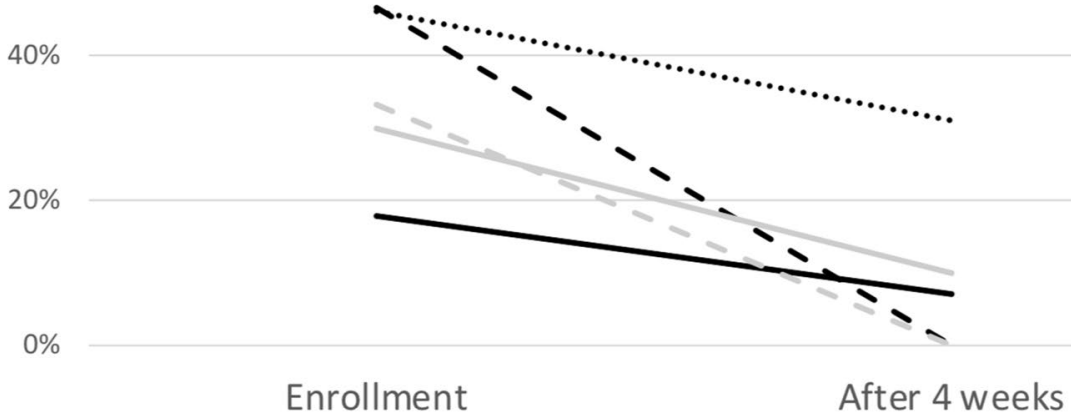


Fig. 3 Rate of patients with $\geq 1$ CTC at enrollment and after 4 weeks of therapy and patients with progression of disease (PD) after 3 months
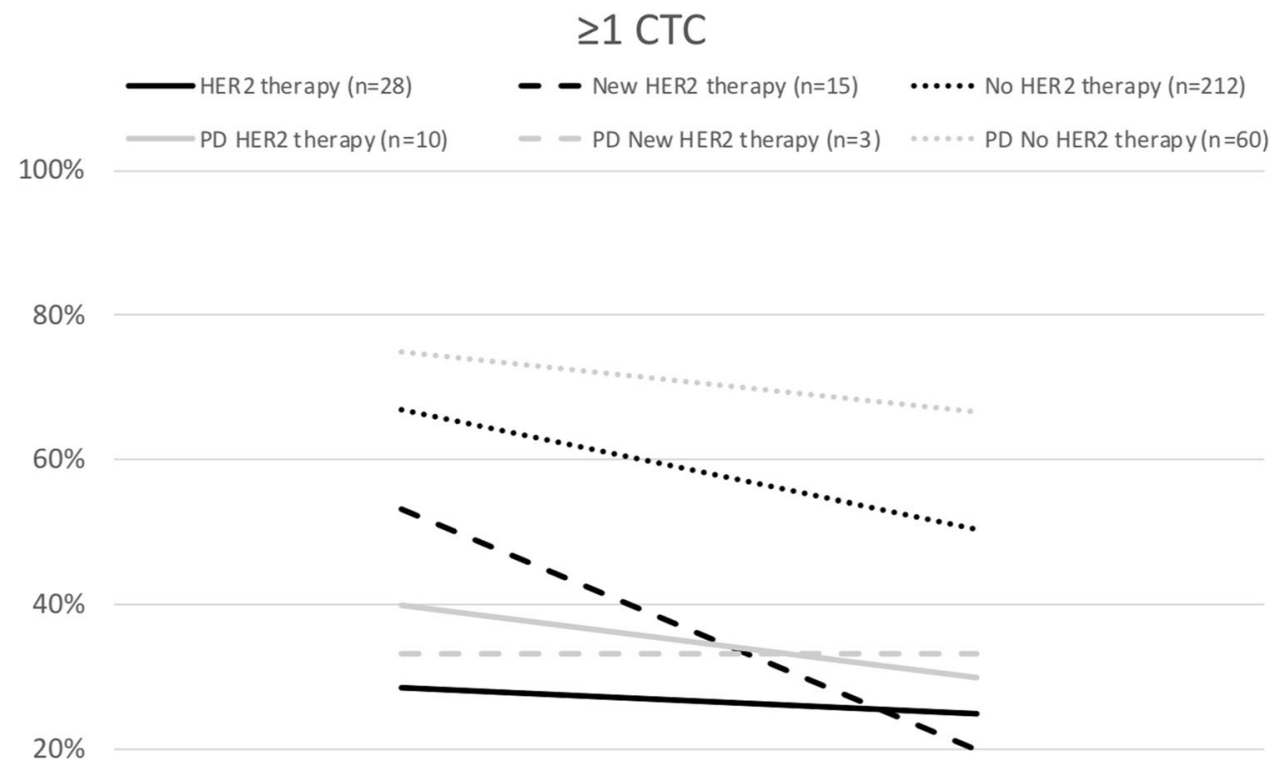

$0 \%$
After 4 weeks
33.3, and 66.7\% ( $p=0.056)$ among those patients with PD. These trends are depicted with the gray bars in Figs. 2 and 3.

Regarding PFS and OS, patients with "New HER2 therapy" had the best prognosis, with a mean PFS of 14.5 months (95\% confidence interval [CI] 5.4-23.7) and mean overall survival of 42.7 months (95\% CI 33.0-52.5) for OS followed by "No HER2 therapy" with 10.6 months $(95 \%$ CI 8.7-12.4) and 26.8 months (95\% CI 23.9-29.6), respectively, and patients under ongoing "HER2 therapy" with 8.8 months (95\% CI 5.7-11.8) and 26.1 months (95\% CI 19.8-32.3). The "New HER2 therapy" group had received the fewest lines of chemotherapy previously (mean 0.4 , 95\% CI 0.2-0.7) followed by "No HER2 therapy" (mean $1.5,95 \%$ CI 1.3-1.7) and "HER2 therapy" (mean 1.9, 95\% CI 1.3-2.5).

In all, $144(67.9 \%)$ patients of the "No HER2 therapy" group received chemotherapy with palliative intention before being enrolled in the study, $19(9.0 \%)$ patients with metastatic disease had received only endocrine therapy, and $49(23.1 \%)$ patients had not received any palliative therapy before enrollment (Table 2). Furthermore, 54.2\% of the chemotherapy group had a positive CTC status at enrollment, $73.6 \% \geq 1 \mathrm{CTC}$ and $2.8 \% \geq 1$ HER2-positive CTC, compared to $26.3 \%$ positive CTC status, $52.6 \% \geq 1$ CTC and $0.0 \% \geq 1$ HER2-positive CTC of the endocrine therapy group, and $30.6 \%$ positive CTC status, $53.1 \% \geq 1$ CTC and 6.1\% $\geq 1$ HER2-positive CTC in the group with no previous treatment. After 4 weeks of therapy (chemotherapy or endocrine therapy), $36.8 \%$ of the group that had received chemotherapy before enrollment had a positive CTC status, $57.6 \% \geq 1 \mathrm{CTC}$ and $2.8 \% \geq 1$ HER2-positive CTC, compared to $10.5 \%$ positive CTC status, $26.3 \% \geq 1$ CTC and $0.0 \% \geq 1$ HER2-positive CTC of the group that received endocrine therapy before enrollment, and $22.4 \%$ positive CTC status, $38.8 \% \geq 1 \mathrm{CTC}$ and $0.0 \% \geq 1$ HER2positive CTC with no previous treatment before enrollment. In these 3 groups, $32.6,15.8$, and $20.4 \%$, respectively, experienced PD after 3 months. PFS was 10.4 months (95\% CI 8.0-12.8), 13.4 months (95\% CI 7.3-19.5), and 9.9 months (95\% CI 7.0-12.8), respectively, in the three groups. OS was 24.8 months (95\% CI 21.1-28.5), 30.5 months $(95 \%$ CI 22.3-38.8), and 31.0 months (95\% CI 26.0-35.9), respectively.

Table 3 demonstrates the different anti-HER2 therapies that were administered after enrollment in the study. Of the patients under ongoing HER2 therapy, 12 patients received trastuzumab + chemotherapy (eribulin, vinorelbin, paclitaxel, or nab-paclitaxel), 3 patients trastuzumab + pertuzumab + chemotherapy (docetaxel or paclitaxel), 3 patients trastuzumab + lapatinib, T-DM1, and 6 patients received lapatinib + chemotherapy (capecitabine or MTX + cyclophosphamide). After 3 months of therapy, 3 patients who had received trastuzumab + chemotherapy (eribulin or vinorelbin), all 4 patients with T-DM1, and 3 patients with lapatinib + chemotherapy (capecitabine or MTX + cyclophosphamide) showed PD. A decrease in CTCs was shown for trastuzumab + chemotherapy (eribulin, vinorelbin, or paclitaxel) $(n=5)$, trastuzumab + pertuzumab + paclitaxel 
Table 2 Patient characteristics and rate of CTC status of HER2-nonamplified patients (No HER2 therapy) divided by palliative therapy before enrollment

\begin{tabular}{|c|c|c|c|c|c|}
\hline & & $\begin{array}{l}\text { Chemotherapy before } \\
\text { enrollment }\end{array}$ & $\begin{array}{l}\text { Endocrine therapy } \\
\text { before enrollment }\end{array}$ & $\begin{array}{l}\text { No therapy before } \\
\text { enrollment }\end{array}$ & $p$ \\
\hline Total & $n$ & 144 & 19 & 49 & \\
\hline$\geq 1 \mathrm{CTC}$ at enrollment & Rate & $73.6 \%$ & $52.6 \%$ & $53.1 \%$ & 0.012 \\
\hline$\geq 5 \mathrm{CTC}$ at enrollment & Rate & $54.2 \%$ & $26.3 \%$ & $30.6 \%$ & 0.003 \\
\hline$\geq 1$ HER2-positive CTC at enrollment & Rate & $2.8 \%$ & $0.0 \%$ & $6.1 \%$ & 0.369 \\
\hline$\geq 1 \mathrm{CTC}$ after 4 weeks & Rate & $57.6 \%$ & $26.3 \%$ & $38.8 \%$ & 0.006 \\
\hline$\geq 5 \mathrm{CTC}$ after 4 weeks & Rate & $36.8 \%$ & $10.5 \%$ & $24.5 \%$ & 0.032 \\
\hline$\geq 1$ HER2-positive CTC after 4 weeks & Rate & $2.8 \%$ & $0.0 \%$ & $0.0 \%$ & 0.062 \\
\hline \multirow[t]{2}{*}{ PD after 3 months } & $n$ & 47 & 3 & 10 & \\
\hline & Rate & $32.6 \%$ & $15.8 \%$ & $20.4 \%$ & 0.116 \\
\hline Age at diagnosis BC & $\begin{array}{l}\text { Mean } \\
(95 \% \mathrm{CI})\end{array}$ & $\begin{array}{l}50.0 \text { years } \\
(48.3-51.7)\end{array}$ & $\begin{array}{l}56.5 \text { years } \\
(51.5-61.4)\end{array}$ & $\begin{array}{l}55.0 \text { years } \\
(51.6-58.5)\end{array}$ & 0.014 \\
\hline Age at enrollment & $\begin{array}{l}\text { Mean } \\
(95 \% \mathrm{CI})\end{array}$ & $\begin{array}{l}58.7 \text { years } \\
(56.9-60.6)\end{array}$ & $\begin{array}{l}63.3 \text { years } \\
(58.2-68.4)\end{array}$ & $\begin{array}{l}59.5 \text { years } \\
(56.1-62.8)\end{array}$ & 0.513 \\
\hline Number CHT met & $\begin{array}{l}\text { Mean } \\
(95 \% \mathrm{CI})\end{array}$ & $\begin{array}{l}2.2 \\
(1.9-2.4)\end{array}$ & $\begin{array}{l}0 \\
(0.0-0.0)\end{array}$ & $\begin{array}{l}0 \\
(0.0-0.0)\end{array}$ & $<0.001$ \\
\hline Endocrine therapy met & Rate & $63.2 \%$ & $100 \%$ & $0 \%$ & $<0.001$ \\
\hline PFS & $\begin{array}{l}\text { Mean } \\
(95 \% \mathrm{CI})\end{array}$ & $\begin{array}{l}10.4 \text { months } \\
(8.0-12.8)\end{array}$ & $\begin{array}{l}13.4 \text { months } \\
(7.3-19.5)\end{array}$ & $\begin{array}{l}9.9 \text { months } \\
(7.0-12.8)\end{array}$ & 0.955 \\
\hline OS & $\begin{array}{l}\text { Mean } \\
(95 \% \mathrm{CI})\end{array}$ & $\begin{array}{l}24.8 \text { months } \\
(21.1-28.5)\end{array}$ & $\begin{array}{l}30.5 \text { months } \\
(22.3-38.8)\end{array}$ & $\begin{array}{l}31.0 \text { months } \\
(26.0-35.9)\end{array}$ & 0.065 \\
\hline
\end{tabular}

Table 3 Number of patients with HER2-targeted therapies and combined chemotherapies after enrollment. Number of patients with progression of disease (PD) under anti-HER2 therapy

\begin{tabular}{|c|c|c|c|c|}
\hline Anti-HER2 therapy & Chemotherapy & & $\begin{array}{l}\text { HER2 } \\
\text { therapy } \\
n\end{array}$ & $\begin{array}{l}\text { New } \\
\text { HER2 } \\
\text { therapy } \\
n\end{array}$ \\
\hline \multirow[t]{2}{*}{ Trastuzumab } & \multirow{2}{*}{$\begin{array}{l}\text { Docetaxel/Eribulin/Vinorelbin/ Pacli- } \\
\text { taxel/nab-Paclitaxel }\end{array}$} & Total & 12 & 3 \\
\hline & & PD & 3 & 0 \\
\hline \multirow[t]{2}{*}{ Trastuzumab + Pertuzumab } & \multirow[t]{2}{*}{ Docetaxel/Paclitaxel/ Vinorelbin } & Total & 3 & 5 \\
\hline & & PD & 0 & 0 \\
\hline \multirow[t]{2}{*}{ Trastuzumab + Pertuzumab } & \multirow[t]{2}{*}{ No } & Total & 0 & 1 \\
\hline & & PD & 0 & 0 \\
\hline \multirow[t]{2}{*}{ Trastuzumab + Lapatinib } & \multirow[t]{2}{*}{ No } & Total & 3 & 0 \\
\hline & & PD & 0 & 0 \\
\hline \multirow[t]{2}{*}{ T-DM1 } & \multirow[t]{2}{*}{ No } & Total & 4 & 4 \\
\hline & & PD & 4 & 2 \\
\hline \multirow[t]{2}{*}{ Lapatinib } & \multirow[t]{2}{*}{ Capecitabin/ MTX + Cyclophosphamid } & Total & 6 & 0 \\
\hline & & PD & 3 & 0 \\
\hline \multirow[t]{2}{*}{ Pertuzumab } & \multirow[t]{2}{*}{ Paclitaxel } & Total & 0 & 2 \\
\hline & & PD & 0 & 1 \\
\hline
\end{tabular}

$(n=1)$, and lapatinib + capecitabine $(n=1)$. An increase in CTCs was observed for trastuzumab + vinorelbin $(n=1)$, trastuzumab + lapatinib $(n=1)$, and lapatinib + capecitabine $(n=2)$. In the "New HER2 therapy" group, 3 patients received trastuzumab + chemotherapy (docetaxel or vinorelbin), 5 patients trastuzumab + pertuzumab + chemotherapy (docetaxel, paclitaxel, or vinorelbin), 1 patient trastuzumab + pertuzumab, 4 patients T-DM1, and 2 patients pertuzumab + paclitaxel. PD was observed in 2 patients who had received T-DM1 and in 1 patient with pertuzumab + paclitaxel. A decrease in CTCs was shown for trastuzumab + docetaxel $(n=1)$, trastuzumab + pertuzumab + docetaxel $(n=3)$, trastuzumab + pertuzumab 
$(n=1)$, and T-DM1 $(n=3)$. No increase in CTCs was observed in the "New HER2 therapy" group.

\section{Discussion}

In this analysis, the CTC status of patients with MBC, stratified by ongoing therapy and previous treatment, was investigated. The point prevalence of CTC at enrollment was highest in patients receiving ongoing palliative chemotherapy for HER2-nonamplified stage IV breast cancer. Throughout all therapy groups, a decrease in CTCs was observed after 4 weeks of a new line of palliative therapy (Figs. 2 and 3). Even for the patients in whom disease had progressed after 3 months of therapy, a tendency for CTCs to decrease is evident, as demonstrated by the gray bars in Figs. 2 and 3. As described in multiple studies previously, less reduction or persistence of CTCs under therapy correlates with PD [13, 16, 39, $42,43]$. Therefore, patients were not only divided in groups with $<$ or $\geq 5$ CTCs but also in $<$ or $\geq 1$ CTC at enrollment and after 4 weeks of therapy. Looking at the HER2-nonamplified patients, divided by palliative therapy just before enrollment, the subgroups with the highest rates of PD had also higher rates of CTCs at the time of enrollment (Table 2). This supports the theory proposed by Cristofanilli et al., whereby MBC can be divided into stage IV aggressive and stage IV indolent disease depending on CTC status [15]. Nevertheless, patients with HER2-positive disease do not seem to fit to this theory. At enrollment, the "New HER2 therapy" group had significantly higher CTC values than the "HER2 therapy" group $(\geq 1$ CTC; 53.3 vs. $28.6 \%$ and $\geq 5$ CTCs; 46.7 vs. $17.9 \% ; p<0.001$, respectively, $p=0.02$ ). In contrast, the PFS and OS were significantly better here with 14.5 vs. 8.8 months and 42.7 vs. 26.1 months. This was accompanied by a decrease in $\geq 1$ CTC rate of $23.3 \%$ (vs. $3.6 \%$ ) and $\geq 5$ CTCs rate of $46.7 \%$ (vs. $10.8 \%$ ) within 4 weeks of therapy (Figs. 2 and 3). Of note is also the significantly higher rate of HER2-positive CTCs in the "New HER2 therapy" group at enrollment (40.0 vs. 3.6\% $[p<0.001])$ and the reduction to $0 \%$ (vs. $7.1 \%$ [ $p=0.187]$ ) after 4 weeks of HER2-targeted therapy (Table 1). It needs to be considered that the "HER2 therapy" group had a mean of 1.9 (range 1.3-2.5) previous palliative chemotherapy lines, whereas the "New HER2 therapy" group had a mean of only 0.4 (range $0.2-0.7$ ) lines of previous chemotherapy in the metastatic situation. This partly explains the advantages in PFS and OS. These findings are conclusive with Giardano et al., who stated that the baseline CTC count of HER2-positive patients is least valuable for prognostic prediction suggesting an interaction between CTCs and HER2-targeted therapies [44]. However, they didn't distinguish between ongoing palliative HER2-targeted treatment and de novo HER2-positive MBC. Regarding only patients with first-line chemotherapy for $\mathrm{MBC}$, Pierga et al. revealed that CTC decrease seems strongest under targeted therapy [45]. These findings were also confirmed by our results.

The impact of CTC status in de novo MBC and the correlation between first-line HER2-targeted therapy vs. first-line endocrine and chemotherapy is apparent when comparing the "New HER2 therapy" group with the "No therapy before enrollment" group of the HER2-nonamplified subgroup; the prevalence of $\geq 1 \mathrm{CTC}$ at enrollment was similar (53.3 vs. $53.1 \%$ ) but the rate of positive CTC status ( $\geq 5 \mathrm{CTC}$ ) at enrollment was higher in the "New HER2 therapy" group (46.7 vs. $30.6 \%)$. After 4 weeks of therapy, $\geq 1$ CTC were found in 20.0 vs. $38.8 \%$ of patients and a positive CTC status was observed in 0 vs. $22.4 \%$ of patients. PD rate was similar at 20.0 vs. $20.4 \%$. PFS and OS were better in the "New HER2 therapy" group (14.5 vs. 9.9 months, 42.7 vs. 31.0 months, respectively).

As other retrospective studies and xenograft models have shown that HER2-targeted monoclonal antibody therapies might even be able to target HER2-nonamplified cancer cells and cancer stem cell populations including CTCs, the indication for HER2-targeted therapies might need to be extended $[25,26]$. Antibody-dependent, cell-mediated cytotoxicity (ADCC) might impact a subgroup of patients showing heterogenic tumor spread, represented by CTCs. Nevertheless, these findings also demonstrate that low rates of CTC levels do not necessarily correlate with better prognosis in crosstherapy comparisons. Negative phase-II trials, such as the TREAT-CTC trial, with the intention to treat CTCs of HER2nonamplified patients, illustrate the complexity of the matter [27]. The clinical significance of the CTC phenotype for guiding therapeutic decisions is currently being investigated in the DETECT studies [46].

The clinical relevance of CTC status on prognosis, including HER2-positive patients, is undisputed [15]. These findings lead us to assume that the CTC status might be strongly affected by HER2-targeted therapies but does not necessarily correlate with prognosis in patients with HER2-positive de novo $\mathrm{MBC}$ as compared to HER2-nonamplified de novo MBC. Furthermore, the CTC status of HER2-positive patients needs to be evaluated according to the therapy situation (before vs. ongoing anti-HER 2 therapy). This is underlined by the observation that patients receiving HER2-targeted therapy have, independent of the prognosis, significantly lower levels of CTCs than patients receiving chemotherapy, endocrine therapy, or no therapy (Fig. 2 and 3). This overall decrease in CTC count must be considered when comparing different therapy groups. 


\section{Limitations}

One main limitation lies in the fact that this is a retrospective analysis. Another limitation is the small number of analyzed patients in the "HER2 Therapy" and "New HER2 therapy" groups. Indeed, the small number of patients with PD highlights the implicit difficulties in analyzing the rate of CTCpositive cases. The subgroup receiving anti-HER2 therapy can therefore only be reported descriptively and used to generate new hypotheses about therapy effects on CTC levels.

\section{Conclusions}

First-line HER2-targeted therapy of metastatic breast cancer seems to reduce CTC levels greater than endocrine or chemotherapy. Ongoing anti-HER2 therapy seems to be associated with lower overall CTC levels.

Acknowledgements Open Access funding provided by Projekt DEAL. The authors gratefully acknowledge all patients whose data were used in this study. We also thank the medical and nursing staff at the National Center for Tumor Diseases (NCT; Heidelberg) for excellent management and care of our patients, the NCT laboratory staff, and the laboratory staff at the Institute of Tumor Biology in Hamburg, which provided excellent technical assistance in determining the CTCs. This study was supported by NCT in-house funds, made available to AS and AT, and by grants to AT from the BioRN Leading Edge Cluster "Molecular and Cell-Based Medicine" (BRN 02GS1893), supported by the German Federal Ministry of Education and Research (BMBF), Berlin, Germany (BMBF N02/74829) and the Dietmar Hopp Foundation. Moreover, this study was supported by the ERC-2010-AdG_20100317 DISSECT to KP.

Author contributions TMD, SR, MW, ADH, KP, AT, and AS jointly conceived the study and developed the design. MW and AS supervised the study. SR and KP developed the methodology. TMD, CF, JN, ADH, MF, KP, AT, AS, and MW participated in patient recruitment, patient management, clinical data collection, sample collection, and sample analysis. TMD, ChF, and JN organized and reported the data, constructed the databases, and managed the data. TMD and MF performed the statistical analysis. TMD, CF, MF, ADH, AS, and MW participated in data analysis and interpretation. TMD, MF, AS, and MW drafted the manuscript. TMD, SR, CF, MF, JN, ChF, ADH, KP, AT, FS, AS, and MW revised the draft manuscript for important intellectual input. TMD prepared the final manuscript. All authors read and approved the final manuscript.

\section{Compliance with ethical standards}

Conflict of interest The authors declare that they have no conflict of interest.

Ethical approval All procedures performed in studies involving human participants were in accordance with the ethical standards of the Institutional and/or National Research Committee and with the 1964 Helsinki Declaration and its later amendments or comparable ethical standards. This article does not contain any studies with animals performed by any of the authors.
Open Access This article is licensed under a Creative Commons Attribution 4.0 International License, which permits use, sharing, adaptation, distribution and reproduction in any medium or format, as long as you give appropriate credit to the original author(s) and the source, provide a link to the Creative Commons licence, and indicate if changes were made. The images or other third party material in this article are included in the article's Creative Commons licence, unless indicated otherwise in a credit line to the material. If material is not included in the article's Creative Commons licence and your intended use is not permitted by statutory regulation or exceeds the permitted use, you will need to obtain permission directly from the copyright holder. To view a copy of this licence, visit http://creativecommons.org/licenses/by/4.0/.

\section{References}

1. Jemal A, Bray F, Center MM, Ferlay J, Ward E, Forman D (2011) Global cancer statistics. CA Cancer J Clin 61(2):69-90

2. Ghoncheh M, Pournamdar Z, Salehiniya H (2016) Incidence and mortality and epidemiology of breast cancer in the World. Asian Pac J Cancer Prev 17(S3):43-46

3. Siegel RL, Miller KD, Jemal A (2018) Cancer statistics, 2018. CA Cancer J Clin 68(1):7-30

4. Harbeck N, Gnant M (2017) Breast cancer. Lancet 389(10074):1134-1150

5. Hennigs A, Riedel F, Gondos A, Sinn P, Schirmacher P, Marme F, Jager D, Kauczor HU, Stieber A, Lindel K et al (2016) Prognosis of breast cancer molecular subtypes in routine clinical care: a large prospective cohort study. BMC Cancer 16(1):734

6. Hudis CA (2007) Drug therapy: Trastuzumab-mechanism of action and use in clinical practice. N Engl J Med 357(1):39-51

7. Slamon DJ, Clark GM, Wong SG, Levin WJ, Ullrich A, Mcguire WL (1987) Human-breast cancer-correlation of relapse and survival with amplification of the Her-2 Neu oncogene. Science 235(4785):177-182

8. Slamon DJ, Godolphin W, Jones LA, Holt JA, Wong SG, Keith DE, Levin WJ, Stuart SG, Udove J, Ullrich A et al (1989) Studies of the HER-2/neu proto-oncogene in human breast and ovarian cancer. Science 244(4905):707-712

9. Ravdin PMC, Chamness GC (1995) The c-erbB-2 proto-oncogene as a prognostic and predictive marker in breast cancer: a paradigm for the development of other macromolecular markers_-a review. Gene 159(1):19-27

10. Cobleigh MA, Vogel CL, Tripathy D, Robert NJ, Scholl S, Fehrenbacher L, Wolter JM, Paton V, Shak S, Lieberman G et al (1999) Multinational study of the efficacy and safety of humanized antiHER2 monoclonal antibody in women who have HER2-overexpressing metastatic breast cancer that has progressed after chemotherapy for metastatic disease. J Clin Oncol 17(9):2639-2648

11. Yates LR, Campbell PJ (2012) Evolution of the cancer genome. Nat Rev Genet 13(11):795-806

12. Cristofanilli M (2014) Circulating tumour cells: telling the truth about metastasis. Lancet Oncol 15(4):365-366

13. Toss A, Mu Z, Fernandez S, Cristofanilli M (2014) CTC enumeration and characterization: moving toward personalized medicine. Ann Transl Med 2(11):108

14. Bidard FC, Madic J, Mariani P, Piperno-Neumann S, Rampanou A, Servois V, Cassoux N, Desjardins L, Milder M, Vaucher I et al (2014) Detection rate and prognostic value of circulating tumor cells and circulating tumor DNA in metastatic uveal melanoma. Int J Cancer Int Cancer 134(5):1207-1213

15. Cristofanilli M, Pierga JY, Reuben J, Rademaker A, Davis AA, Peeters DJ, Fehm T, Nole F, Gisbert-Criado R, Mavroudis D et al (2019) The clinical use of circulating tumor cells (CTCs) 
enumeration for staging of metastatic breast cancer (MBC): International expert consensus paper. Crit Rev Oncol Hematol 134:39-45

16. Smerage JB, Barlow WE, Hortobagyi GN, Winer EP, LeylandJones B, Srkalovic G, Tejwani S, Schott AF, O'Rourke MA, Lew DL et al (2014) Circulating tumor cells and response to chemotherapy in metastatic breast cancer: SWOG S0500. J Clin Oncol 32(31):3483-3489

17. Wallwiener M, Hartkopf AD, Baccelli I, Riethdorf S, Schott S, Pantel K, Marme F, Sohn C, Trumpp A, Rack B et al (2013) The prognostic impact of circulating tumor cells in subtypes of metastatic breast cancer. Breast Cancer Res Treat 137(2):503-510

18. Van Poznak C, Somerfield MR, Bast RC, Cristofanilli M, Goetz MP, Gonzalez-Angulo AM, Hicks DG, Hill EG, Liu MC, Lucas $\mathrm{W}$ et al (2015) Use of biomarkers to guide decisions on systemic therapy for women with metastatic breast cancer: American Society of Clinical Oncology Clinical Practice Guideline. J Clin Oncol 33(24):2695-2704

19. AGO e. V. in der DGGG e.V. sowie in der DKG e.V.: Guidelines Breast Version 2020.1D. www.ago-onlinede

20. Cristofanilli M, Budd GT, Ellis MJ, Stopeck A, Matera J, Miller MC, Reuben JM, Doyle GV, Allard WJ, Terstappen LW et al (2004) Circulating tumor cells, disease progression, and survival in metastatic breast cancer. N Engl J Med 351(8):781-791

21. Aktas B, Kasimir-Bauer S, Muller V, Janni W, Fehm T, Wallwiener D, Pantel K, Tewes M, Group DS (2016) Comparison of the HER2, estrogen and progesterone receptor expression profile of primary tumor, metastases and circulating tumor cells in metastatic breast cancer patients. BMC Cancer 16:522

22. Meng S, Tripathy D, Shete S, Ashfaq R, Haley B, Perkins S, Beitsch P, Khan A, Euhus D, Osborne C et al (2004) HER-2 gene amplification can be acquired as breast cancer progresses. Proc Natl Acad Sci USA 101(25):9393-9398

23. Wallwiener M, Hartkopf AD, Riethdorf S, Nees J, Sprick MR, Schonfisch B, Taran FA, Heil J, Sohn C, Pantel K et al (2015) The impact of HER2 phenotype of circulating tumor cells in metastatic breast cancer: a retrospective study in 107 patients. BMC Cancer $15: 403$

24. Müller V, Alix-Panabières C, Pantel K (2010) Insights into minimal residual disease in cancer patients: Implications for anti-cancer therapies. Eur J Cancer 46(7):1189-1197

25. Ithimakin S, Day KC, Malik F, Zen Q, Dawsey SJ, Bersano-Begey TF, Quraishi AA, Ignatoski KW, Daignault S, Davis A et al (2013) HER2 drives luminal breast cancer stem cells in the absence of HER2 amplification: implications for efficacy of adjuvant trastuzumab. Can Res 73(5):1635-1646

26. Georgoulias V, Bozionelou V, Agelaki S, Perraki M, Apostolaki S, Kallergi G, Kalbakis K, Xyrafas A, Mavroudis D (2012) Trastuzumab decreases the incidence of clinical relapses in patients with early breast cancer presenting chemotherapy-resistant CK-19mRNApositive circulating tumor cells: results of a randomized phase II study. Ann Oncol 23(7):1744-1750

27. Ignatiadis M, Litiere S, Rothe F, Riethdorf S, Proudhon C, Fehm T, Aalders K, Forstbauer H, Fasching PA, Brain E et al (2018) Trastuzumab versus observation for HER2 nonamplified early breast cancer with circulating tumor cells (EORTC 90091-10093, BIG 1-12, Treat CTC): a randomized phase II trial. Ann Oncol 29(8):1777-1783

28. Therasse P, Arbuck SG, Eisenhauer EA, Wanders J, Kaplan RS, Rubinstein L, Verweij J, Van Glabbeke M, van Oosterom AT, Christian MC et al (2000) New guidelines to evaluate the response to treatment in solid tumors. European Organization for Research and Treatment of Cancer, National Cancer Institute of the United States, National Cancer Institute of Canada. J Natl Cancer Inst 92(3):205-216
29. Edgerton SM, Moore D 2nd, Merkel D, Thor AD (2003) erbB-2 (HER-2) and Breast Cancer Progression. Appl Immunohistochem Mol Morphol 11(3):214-221

30. Solomayer EF, Becker S, Pergola-Becker G, Bachmann R, Kramer B, Vogel U, Neubauer H, Wallwiener D, Huober J, Fehm TN (2006) Comparison of HER2 status between primary tumor and disseminated tumor cells in primary breast cancer patients. Breast Cancer Res Treat 98(2):179-184

31. Gancberg D, Di Leo A, Cardoso F, Rouas G, Pedrocchi M, Paesmans M, Verhest A, Bernard-Marty C, Piccart MJ, Larsimont D (2002) Comparison of HER-2 status between primary breast cancer and corresponding distant metastatic sites. Ann Oncol 13(7):1036-1043

32. Fehm T, Hoffmann O, Aktas B, Becker S, Solomayer EF, Wallwiener D, Kimmig R, Kasimir-Bauer S (2009) Detection and characterization of circulating tumor cells in blood of primary breast cancer patients by RT-PCR and comparison to status of bone marrow disseminated cells. Breast Cancer Res 11(4):R59

33. Giordano A, Gao H, Anfossi S, Cohen E, Mego M, Lee BN, Tin S, De Laurentiis M, Parker CA, Alvarez RH et al (2012) Epithelial-mesenchymal transition and stem cell markers in patients with HER2-positive metastatic breast cancer. Mol Cancer Ther 11(11):2526-2534

34. Giuliano M, Giordano A, Jackson S, Hess KR, De Giorgi U, Mego M, Handy BC, Ueno NT, Alvarez RH, De Laurentiis M et al (2011) Circulating tumor cells as prognostic and predictive markers in metastatic breast cancer patients receiving first-line systemic treatment. Breast Cancer Res 13(3):R67

35. Mehes G, Witt A, Kubista E, Ambros PF (2001) Circulating breast cancer cells are frequently apoptotic. Am J Pathol 159(1):17-20

36. Riethdorf S, Pantel K (2008) Disseminated tumor cells in bone marrow and circulating tumor cells in blood of breast cancer patients: current state of detection and characterization. Pathobiology 75(2): 140-148

37. Rossi E, Basso U, Celadin R, Zilio F, Pucciarelli S, Aieta M, Barile C, Sava T, Bonciarelli G, Tumolo S et al (2010) M30 neoepitope expression in epithelial cancer: quantification of apoptosis in circulating tumor cells by Cell Search analysis. Clin Cancer Res 16(21):5233-5243

38. Cristofanilli M (2009) The biological information obtainable from circulating tumor cells. Breast 18(Suppl 3):S38-40

39. Deutsch TM, Riethdorf S, Nees J, Hartkopf AD, Schonfisch B, Domschke C, Sprick MR, Schutz F, Brucker SY, Stefanovic S et al (2016) Impact of apoptotic circulating tumor cells (aCTC) in metastatic breast cancer. Breast Cancer Res Treat 160(2):277-290

40. Hartkopf AD, Taran FA, Wallwiener M, Hagenbeck C, Melcher C, Krawczyk N, Hahn M, Wallwiener D, Fehm T (2013) The presence and prognostic impact of apoptotic and nonapoptotic disseminated tumor cells in the bone marrow of primary breast cancer patients after neoadjuvant chemotherapy. Breast Cancer Res 15(5):R94

41. R: a language and environment for statistical computing. https:// www.r-project.org

42. Wallwiener M, Riethdorf S, Hartkopf AD, Modugno C, Nees J, Madhavan D, Sprick MR, Schott S, Domschke C, Baccelli I et al (2014) Serial enumeration of circulating tumor cells predicts treatment response and prognosis in metastatic breast cancer: a prospective study in 393 patients. BMC Cancer 14:512

43. Deutsch TM, Stefanovic S, Feisst M, Fischer C, Riedel F, Fremd C, Domschke C, Pantel K, Hartkopf AD, Sutterlin M et al (2020) Cut-off analysis of CTC change under systemic therapy for defining early therapy response in metastatic breast cancer. Cancers 12:4

44. Giordano A, Giuliano M, De Laurentiis M, Arpino G, Jackson S, Handy BC, Ueno NT, Andreopoulou E, Alvarez RH, Valero V et al (2012) Circulating tumor cells in immunohistochemical subtypes of metastatic breast cancer: lack of prediction in HER2-positive disease treated with targeted therapy. Ann Oncol 23(5):1144-1150 
45. Pierga JY, Hajage D, Bachelot T, Delaloge S, Brain E, Campone M, Dieras V, Rolland E, Mignot L, Mathiot C et al (2012) High independent prognostic and predictive value of circulating tumor cells compared with serum tumor markers in a large prospective trial in first-line chemotherapy for metastatic breast cancer patients. Ann Oncol 23(3):618-624

46. Schramm A, Friedl TW, Schochter F, Scholz C, de Gregorio N, Huober J, Rack B, Trapp E, Alunni-Fabbroni M, Muller V et al (2016) Therapeutic intervention based on circulating tumor cell phenotype in metastatic breast cancer: concept of the DETECT study program. Arch Gynecol Obstet 293(2):271-281

Publisher's Note Springer Nature remains neutral with regard to jurisdictional claims in published maps and institutional affiliations. 